To cite this article: Hadiza Umar \& Victoria Sokari (2020) Challenges Associated with Utilization of Legal Information Resources by Postgraduate Law Students in Federal Universities of Northern Nigeria. Information Impact: Journal of Information and Knowledge Management, 11:1, 40-47, DOI: dx.doi.org/10.4314/iijikm.v11i1.4

To link to this article: https://doi.org/10.4314/iijikm.v11i1.4

\title{
Challenges Associated with Utilization of Legal Information Resources by Postgraduate Law Students in Federal Universities of Northern Nigeria
}

\author{
${ }^{1}$ Hadiza Umar and ${ }^{1}$ Victoria Sokari \\ ${ }^{1}$ University Library, Bayero University, Kano, Nigeria
}

\begin{abstract}
The paper investigates the challenges associated with utilization of legal information resources in the faculty of law libraries in federal universities of northern Nigeria. The study employed quantitative research method using crosssectional survey research design. The population of the study comprised of 1,348 postgraduate law students in the libraries studied. Simple random sampling equation (SRS-Equation) was used to select the sample size for the study. A total of 308 postgraduate law students was therefore the sample size chosen for the study. A self-developed questionnaire was used to collect data. A total number of 308 copies of questionnaire were administered personally by the author and 4 research assistants, out of which 271 were returned and found useful for further analysis. Data collected was analyzed using descriptive statistics with the aid of SPSS (v21). Findings revealed that, the printed legal information resources were highly utilized by postgraduate law students except e-resources and on-line legal databases that had low utilization. Some challenges associated with the utilization of legal resources were insufficient copies of books, inadequate reading facilities and defaced information resources; inadequate infrastructure for accessing resources electronically, insufficient computers and interrupted power supply, among others. The study concludes that, despite the technological advancement and globalization the world is experiencing, postgraduate law students in federal universities of northern Nigeria are yet to fully enjoy the vast electronic legal information resources, and this could significantly affect the quality of legal researches and academic excellence in legal profession. The study recommends among other things the need for the provision of adequate electronic legal information resources and regular subscription to online legal databases in the faculty of law libraries in federal universities in northern Nigeria.
\end{abstract}

Keywords Utilization, Legal Information Resources, Postgraduates, Law students, Libraries

CONTACT Hadiza Umar \& Victoria Sokari hadizaumar03@gmail.com University Library Bayero University, Kano, Nigeria 2020 The Authors Published with License by Information Impact 


\section{Introduction}

Legal information resources are essential ingredients for effective legal research undertaken by postgraduate students. Law information resources could be referred to as legal literature such as: law books, law reports, legislation and statutes, legal periodicals, government publications, reference materials and other inter-related non-legal books, e-resources, unpublished works of law - for example conference papers, theses on law, and so on. These resources can be used for legal research productivity which includes, research publication in professional journals and in conference proceedings, writing a book or chapter, gathering and analyzing original evidence, working with other post-graduate students on dissertations and class projects, obtaining research grants, carrying out editorial duties, obtaining patents and licenses, writing monographs, developing experimental designs, producing works of an artistic or creative nature and engaging in public debates and commentaries.

Despite the consensus by experts that, the complexity of the legal profession naturally demands maximum information resource utilisation for appropriate and effective legal activities, the utilization of these resources in faculty of law libraries is faced with several challenges (Ossai, 2011, Uluocha \& Mabawonku 2014; Mostert \& Olorunfemi, 2013). This is why Adeleke (2005) rightly asserts that if the library is to contribute to the advancement of knowledge, it must not only provide resources but also, identify the challenges affecting utilization of the resources by its clientele. Legal information resources in Nigeria Universities are of crucial importance to law students and the entire legal profession. Law libraries play a key role in providing law information resources which are indispensable tools in supporting legal teaching, research and practices. These law libraries normally acquire legal materials (printed and non-printed materials), process and make them available for use to the users (Abdullahi, 2011).

Legal profession is one which requires the use of relevant, timely and current information resources in various formats. However, it has been observed by the researcher that there is little or no literature that investigates the challenges affecting the utilization of legal information resources particularly in faculty of law libraries in northern Nigeria. Therefore, understanding the problem of underutilization of legal information resources in faculty of law libraries with a view to proffer solution is essential to law librarians and researchers in the area of law librarianship. It is against this background that this study attempts to investigate "challenges associated with utilization of legal information resources by postgraduate law students in federal universities of northern Nigeria.

\section{Objective of the study}

The main purpose of the study is to investigate the challenges associated with utilization of legal information resources by postgraduate law students in faculty of law libraries in federal universities of northern Nigeria. Specifically, the objectives are:

1) To determine the types of legal information resources utilized by postgraduate law students in faculty of law libraries in federal universities of northern Nigeria.

2) To determine the challenges associated with the utilization of legal information resources by postgraduate law students in the libraries under study. 
3) To identify the solutions to overcome the challenges associated with utilization of legal information resources in the libraries under study.

\section{Literature review}

Legal information resources are essential ingredients for effective legal research. Thus, legal information resources, according to Mabawonku (2014) could be referred to as legal literature such as law books, law reports, legislation and statutes, legal periodicals, government publications, reference materials and other inter-related non-legal books. In addition, E-resources, unpublished works of law, such as conference papers, theses and dissertation on law, students project reports on law and so on. Legal information resources are indispensable tools of legal education. Hence, availability of such information resources entails the availability, provision and supply of the needed legal information resources at the right quantity and the right time.

The utilization of various types of legal information resources, both print and electronic, allows for access to a wide variety of information which is essential for scholarly activities. Utilization of information resources in law libraries is the process through which legal information resources are used. It is the maximum usage of information resources since it is expected that all types of legal information resources available in faculty of law libraries should be encouraged to be utilized. There are many reasons which make postgraduate students utilize the resources of their libraries, some of which include: teaching and learning, legal and non-legal research, moot court practice, writing assignments and presentations, leisure and entertainment (Mallik \& Sen 2008). As such, it is expected that postgraduate law students should be encouraged to utilize all types of information resources for their academic development.

There are numerous challenges affecting the utilization of legal information resources for example; Popoola (2008) posits that the scenario in many libraries in developing countries is under-utilization of information sources and services, partly due to inadequacies in relation to user needs and partly due to poor marketing and user education efforts, coupled with lack of knowledge and awareness of the legal information resources of their libraries.

In addition, there is the problem of management of the resources in terms of their proper and continuous organization that will in turn aid access and retrieval for invariable use by users. In line with this, Amusa and Iyoro (2011) observe that collection management remains a problem in faculty of law libraries. Thus, the inability of faculty of law libraries to continuously organize their information resources would result in users not being able to access and use the information resources adequately. Also, in spite of the increased budget of universities, faculties of law libraries are observed to be hindered by insufficient number of current textbooks and journals. This is supported by Ainoko and Boman (2013) that budget cut is a major challenge facing law libraries which affect their functional roles of acquiring current resources. This is one of the reasons why faculties of law libraries are left with inadequate and current legal information resources. To support this, Owushi and Emasealu (2016) lament that faculty of law libraries which are supposed to be "store houses" of legal knowledge are now without up-to-date books and journals. Hence they no longer perform their prime function of providing current materials for legal teaching and research. Another challenge is theft and mutilation of legal information resources in faculty of law libraries. In line with this submission, Ajidahun (2010) asserted that theft and mutilation of library books are common and that law libraries are not exempted. He further laments that these expensive law books and periodicals are stolen and mutilated on regular and continuous basis with impunity and with compulsion. 
There are other observations and reports that the presence and use of electronic resources in academic libraries is below expectation. For instance, Mostert and Olorunfemi (2013) conducted a study titled "Serving law students: e-readiness and utilization of university e-information facility". The findings revealed that majority $377(63.25 \%$ ) of law students indicated amongst other things that, there is inadequate computers in faculty of law libraries; inadequate internet bandwidth; erratic power supply and; poor network connectivity. These they averred pose serious challenge to their attempt in using legal information resource in the faculty library. This study, therefore, seeks to find out whether these challenges still persist or are have been tackled by the parent institution and stake holders. Thus the data collected for this study would prove whether such challenges exist in law libraries in northern Nigeria or otherwise.

\section{Methodology}

The study adopted quantitative research methodology using survey research design. The population of the study consisted of one thousand three hundred and forty eight (1348) registered postgraduate law students (those who have registered for 2016/2017 academic session in federal universities in Northern states of Nigeria. Simple Random Sampling Equation (SRS-Equation) formula was used to calculate the appropriate sample size in each of the institution to arrive at the sample size of three hundred and eight (308) postgraduate law students as recommended by Research Advisers (2006); were selected for the study out of 1348. The questionnaire was the data collection instrument. The questionnaires were administered and collected by both the researcher and four (4) research assistants. This was done within the class room environment for a period of four months. Data collected were analyzed using descriptive statistics with frequencies and percentages.

\section{Results}

\section{Types of Legal Information Resources Utilized}

Postgraduate law students were asked to indicate the types of legal information resources utilized in their faculty of law libraries.

Table 1: Types of Legal Information Resources Utilized

\begin{tabular}{|c|c|c|c|}
\hline \multirow{2}{*}{$\mathbf{S} / \mathbf{N}$} & \multirow{2}{*}{ Types of Legal Information Resources utilized } & \multicolumn{2}{|c|}{ Frequency \& Percentage } \\
\hline & & $\mathbf{N}$ & $\%$ \\
\hline 1 & Statutes and Statutory Instruments (Acts, Laws, Bye-Laws, Rules and Regulations et.) & 265 & 98.14 \\
\hline 2 & Judicial Decisions (Reported \& Unreported Cases) & 267 & 98.52 \\
\hline 3 & Legal Periodicals (e.g. Law Journals and Magazines) & 264 & 97.42 \\
\hline 4 & Law Books (Textbooks), Legal Dictionaries and Encyclopedias & 271 & 100 \\
\hline 5 & Indexes, Digest and Abstracts & 247 & 91.14 \\
\hline 6 & Treaties and International Laws & 264 & 97.42 \\
\hline 7 & $\begin{array}{l}\text { Government Publications (e.g. Government Acts, Bills, Gazettes, Proclamations, } \\
\text { Statues, Policies etc.) }\end{array}$ & 177 & 65.31 \\
\hline 8 & Non-Legal Materials & 77 & 28.41 \\
\hline 9 & Newspapers & 254 & 93.73 \\
\hline 10 & Lecture Handouts & 42 & 15.49 \\
\hline 11 & Research Reports, Theses \& Dissertations & 271 & 100 \\
\hline 12 & Law Reviews & 257 & 94.83 \\
\hline
\end{tabular}




\begin{tabular}{cccc}
\hline 13 & $\begin{array}{c}\text { E-Resources (e.g. E-Conference proceedings, E-Project Reports, Theses \& } \\
\text { Dissertations, E-Laws of Federation, States and Local Government etc). }\end{array}$ & 68 & 25.09 \\
\hline 14 & $\begin{array}{c}\text { Online Legal Databases (e.g. Lexis Nexis, Westlaw, JSTOR, Hein online, EBSCOHOST } \\
\text { etc.) and Website(s) }\end{array}$ & 82 & 30.26 \\
\hline
\end{tabular}

Table 2 reveals that the postgraduate law students indicated high utilization of 12 out of 14 items listed which were mostly on printed format with more than 50\% response rate. The high response on utilization of these resources could be as a result of high level of awareness and accessibility of the resources in their libraries. Furthermore, from the table, the utilization of electronic information resources is significantly low with (68: 25, 09\%) and online legal databases (82: 30, 26\%) response rate.

\section{Challenges Associated with Legal Information Resources in Law Libraries under Study}

Postgraduate law students were asked to identify from the list of challenges associated with utilization of legal information resources in their libraries.

Table 2: Challenges Associated with the Utilization of Legal Information Resources by Postgraduate Law Students

\begin{tabular}{|c|c|c|c|}
\hline \multirow{2}{*}{$\mathbf{S} / \mathbf{N}$} & \multirow{2}{*}{ Challenges } & \multicolumn{2}{|c|}{ Response } \\
\hline & & $\mathbf{N}$ & $\%$ \\
\hline 1 & Poor organization of legal information resources & 156 & 57.56 \\
\hline 2 & Inadequate current legal information resources & 122 & 45.01 \\
\hline 3 & Lack of borrowing facilities for users & 261 & 96.30 \\
\hline 4 & Inadequate reading facilities in the faculty library & 87 & 32.10 \\
\hline 5 & Many of the print resources are misplaced & 151 & 55.71 \\
\hline 6 & Many of the print resources are mutilated & 196 & 72.32 \\
\hline 7 & Inadequate multiple copies of books & 262 & 96.67 \\
\hline 8 & Problems of Internet connectivity & 270 & 99.63 \\
\hline 9 & Insufficient computers & 251 & 92.62 \\
\hline 10 & Poor local area network connection & 255 & 94.10 \\
\hline 11 & Interrupted power supply & 246 & 90.77 \\
\hline
\end{tabular}

Table 2 shows that most of the challenges are connected to the utilization of electronic legal information resources as unanimously indicated by most postgraduate law students, such as problem of internet connectivity (270: 99, 63\%), interrupted power supply (246: 90, 77\%) and poor local area network connection $(255: 94,10 \%)$. This implies that law libraries are still faced with challenges in the provision of electronic library services to the users. On the other hand, challenges associated with the utilization of printed legal information resources by postgraduate law students are insufficient number of copies of books, non-availability of current resources, lack of organized information resources, lack of borrowing facilities for users, many of the information resources are not well displayed in the library, inadequate reading facilities in the faculty library, and many of the print resources are defaced. The implication of these challenges is that they cause law libraries to be left behind in modern library services and could therefore not be able to compete with those law libraries of the advanced countries.

Table 3:Solutions to Overcome Challenges Associated with Utilization of LIR

\begin{tabular}{cccc}
\hline $\mathbf{S} / \mathbf{N}$ & Solutions & $\mathbf{N}$ & $\%$ \\
\hline 1 & Adequate organization of legal information resources & 247 & 91.14 \\
\hline 2 & Provision of adequate current legal information resources & 200 & 73.80 \\
\hline 3 & Provision of borrowing facilities for users & 271 & 100 \\
\hline 4 & Provision of adequate reading facilities in the faculty library & 87 & 32.10 \\
\hline 5 & Putting adequate security measures in place to prevent book misplacement & 255 & 94.10 \\
\hline 6 & Putting adequate security measures in place to prevent mutilation & 251 & 92.62 \\
\hline
\end{tabular}




\begin{tabular}{cccc}
\hline 7 & Acquisition of multiple copies of books & 261 & 96.31 \\
\hline 8 & Better Internet connectivity & 269 & 99.26 \\
\hline 9 & Provision of sufficient number of computers & 248 & 91.51 \\
\hline 10 & Regular upgrading of local area network connection & 250 & 92.26 \\
\hline 11 & Provision of constant power supply & 243 & 89.67 \\
\hline
\end{tabular}

Postgraduate law students were asked close-ended questions for possible solutions on how to overcome the challenges associated with the utilization of various types of legal information resources in their law libraries. Table 3 shows that $(271,100 \%)$ postgraduate law students suggested provision of borrowing facilities as the major solution to overcome the challenge of inadequate borrowing facilities for users, $(269,99.3 \%)$ mentioned that better internet connectivity should be provided, while $(261,96.3 \%)$ indicated that acquisition of multiple copies of books as the best way to tackle the challenges.

\section{Discussion}

The utilization of legal information resources as revealed by the study shows that all the postgraduate law students in the libraries studied utilize the various types of legal information resources in their libraries such as statutes and statutory instruments, judicial decisions, legal periodicals, law books (textbooks), legal dictionaries \& encyclopedias, newspapers, research reports, theses \& dissertations, law reviews, lecture handouts, indexes, digest and abstracts, government publications, and non-legal materials. This result corroborate the findings of Ossai, (2011) that in University of Benin Nigeria, most of the law students make use of the available library resources in compliance with their academic programs. It was however discovered in this study that the utilization of electronic legal information resources and online legal databases was very low. This could be attributed to the problems of internet connectivity, insufficient computers, interrupted power supply etc. The implication of post graduate law students not adequately utilizing electronic resources and online databases is that they may not have access to more current information for their studies, since information resources in electronic forms and online provide very current information as a result of regular uploads and updates.

The findings of the study also show that the challenges associated with the utilization of printed legal information resources in libraries studied hovers around insufficient of copies of books, nonavailability of current resources, lack of organized information resources, lack of borrowing facilities for users, improper display of the information resources in the library, inadequate reading facilities and defaced information resources as reported by postgraduate law students. On the other hand challenges associated with the utilization of electronic legal information resources were problems of internet connectivity, inadequate infrastructure for accessing resources electronically, poor local area network connection, insufficient computers, and interrupted power supply, unreliability of legal information on internet and invalid library user password and username. This corroborates the finding of Nkamnebe, Udem and Nkamnebe (2014), who stated that the library is deficient in electronic/online library resources. The challenges identified with regards to the utilization of legal resources may hinder them from obtaining quality academic endeavor which also may also affect their output in the course of their career. The solutions to the challenges of utilization of legal information resources as revealed by the study includes the provision of borrowing facilities to overcome the challenge of inadequate borrowing facilities for users; better internet connectivity for adequate use of e-legal resources and; acquisition of multiple copies of books for users. 


\section{Conclusion}

Law libraries in northern Nigeria are faced with numerous challenges in terms of the legal information resources utilized by particularly the postgraduate law students. Most of these challenges are tied to the utilization of electronic legal information resources based on the findings of this study. Despite the technological advancement and globalization the world is experiencing, postgraduate law students in federal universities of northern Nigeria are yet to fully enjoy the vast electronic legal information and online databases that are relevant to their subjects and this could significantly affect the quality of legal researches and academic excellence of the legal profession.

\section{Recommendations}

The study recommends the following:

1. Law libraries should provide adequate electronic legal information resources such as econference proceedings, e-project reports etc in order to meet the information needs of users, especially the postgraduate law students.

2. There should be regular subscription to online legal databases like Lexis Nexis, Westlaw, JSTOR, Hein online, EBSCOHOST and Website(s) for effective utilization by postgraduate law students

3. There should be constant and reliable internet connectivity and alternative power supply as well as provision of adequate infrastructure/facilities that will facilitate the utilization of resources electronically to meet up with the demand of technological era.

\section{References}

Abdullahi, K. A. (2011). Utilization of Information Resources in Law Libraries by the Law Students In Federal Universities of Northern States of Nigeria. (Unpublished Master's thesis). Bayero University, Kano.

Adeleke, A. (2005). Use of Library Resources by Academic Staff in Nigeria Polytechnics. Journal of library science, 12(2), 15-24.

Ainoko, S., \& Boman, D. D. (2013). Information Resources Availability and Use by Legal Practitioners in the Federal Capital Territory of Nigeria. Nigerbiblios, 20(1/2), 29-42.

Ajidahun, C. O. (2010). Theft of law Books in Nigerian University Law Libraries: An Investigative Study. Library Philosophy and Practice. Retrieved from http://digitalcommons.unl.edu/libphilprac/411.

Amusa, O. I., \& Iyoro, A. O. (2011). Appraisal of Classification Schemes and their Effectiveness in Organizing Law Collections in Nigerian Law Faculties. Library Philosophy and Practice, 12 (7) 1-9. Retrieved from http://unllib.unl.edu/LPP/.

Mallik, S., \& Sen, B. K. (2008). Information Sources in Academic Law Libraries in India. Annals of Library and Information Studies, 55(8), 196-203.

Mostert, J. B. \& Olorunfemi, D. Y. (2013). Serving Nigerian Law Students: E-Readiness and Utilisation of University E-Information Facilities. International Journal of Technology and Inclusive Education, Infonomics Society, 2(2), 200-207. 
Nkamnebe, E.C., Udem, O.K., \& Nkamnebe, C.B. (2014). Evaluation of the use of University library resources and services by the students of Paul University, Awka, Anambra State, Nigeria. Library Philosophy and Practice (1147). Retrieved from http://digitalcommons.unl.edu/libphilprac/1147

Ossai, N. B. (2011). How Law Students Utilize Information Resources: A Case Study of the University of Benin, Benin City. International Journal of Library and Information Science, 3(1), 1-14. Retrieved from http://www.academicjournals.org/ijlis.

Owushi, E., \& Emasealu, H. (2016). An Evaluation of Legal Information Resources and Services in Academic law Libraries of Selected Universities in Edo State, Nigeria. Library progress (International), 36(1), 1-12.

Popoola, S. O. (2008). Faculty Awareness and the Use of Library Information Product and Services in Nigerian Universities. Malaysia Journal of Library and Information Science, 13(1), 91-102.

Research Advisors (2006). "Sample Size Determination Table”. Retrieved from https://www.research-advisors.com/

Uluocha, A., \& Mabawonku, I. (2014). Legal information resources, availability and utilization as determinants of law lecturers' research productivity in Nigerian Universities. Journal of Information and Knowledge Management, 4(9). Retrieved from www.iiste.org 